\title{
Enhancing Scientific Thinking Through the Development of Critical Thinking in Higher Education
}

\section{Hyytinen, Heidi}

Palgrave Macmillan

2019-09-23

Hyytinen, H , Toom , A \& Shavelson , R J 2019 , Enhancing Scientific Thinking Through the Development of Critical Thinking in Higher Education . in M Murtonen \& K Balloo (eds), Redefining Scientific Thinking for Higher Education : Higher-Order Thinking,

Evidence-Based Reasoning and Research Skills . Palgrave Macmillan , Cham , pp. 59-78 . https://doi.org/10.1007/9

http://hdl.handle.net/10138/310584

https://doi.org/10.1007/978-3-030-24215-2_3

unspecified

acceptedVersion

Downloaded from Helda, University of Helsinki institutional repository.

This is an electronic reprint of the original article.

This reprint may differ from the original in pagination and typographic detail.

Please cite the original version. 
Hyytinen, H., Toom, A., \& Shavelson, R. J. (2019). Enhancing Scientific Thinking Through the Development of Critical Thinking in Higher Education. In M. Murtonen, \&

K. Balloo (eds.), Redefining Scientific Thinking for Higher Education: Higher-Order

Thinking, Evidence-Based Reasoning and Research Skills (pp. 59-78). Palgrave Macmillan.

\title{
Chapter 3. Enhancing Scientific Thinking Through the Development of Critical Thinking in Higher Education
}

\author{
Heidi Hyytinen and Auli Toom \\ University of Helsinki, Finland \\ Richard J. Shavelson \\ Stanford University, USA
}

\section{Introduction}

Research publications, policy papers and reports have argued that higher education cannot only facilitate learning of domain-specific knowledge and skills, but it also has to promote learning of thinking skills for using that knowledge in action (e.g. Shavelson, 2010a; Greiff et al., 2014; Strijbos, Engels, \& Struyven, 2015). The focus on critical thinking arises, in part, because of higher education's responsibility for preparing individuals to think, reason and cope in and change with an uncertain, continuously and rapidly fluctuating personal and working life (Bok, 2006; Jenert, 2014). The knowledge and skills students need and consequently should be taught in higher education are thus changing; more emphasis needs to be placed on higher-order domain-general or generic skills, such as analytical reasoning and evaluation, problem-solving, argumentation, written communication (e.g. Tremblay, Lalancette, \& Roseveare, 2012; Zahner \& Ciolfi, 2018; Shavelson, 2010b) and collaborative multidisciplinary work (Muukkonen, Lakkala, Toom, \& Ilomäki, 2017). As a part of this discussion, critical thinking is now considered 
a key component of scientific reasoning and a capability to be enhanced in contemporary higher education.

While there is growing consensus on the importance of critical thinking in higher education, the same, however, does not hold true for questions concerning the processes of implementing critical thinking in teaching and learning in programmes (cf. Arum \& Roksa, 2011). While several tips and exercises for how to teach scientific argumentation or reasoning can be found, the literature says surprisingly little about pedagogical principles of integrating critical thinking coherently in teaching and learning. The challenge in intertwining learning of critical thinking to domain-specific courses requires systematic and long-term work processes throughout a student's higher education studies in multiple different kinds of course contexts and themes. The development of critical thinking consisting of a variety of skills requires support, continuous feedback and longterm practice. Yet this is a challenge given the pedagogical organisation of higher education focusing on domain-specific knowledge competencies throughout the degreeprogramme curricula.

In this chapter, we begin by elaborating the definition of critical thinking and presenting justifications for teaching critical thinking. Our first aim is to understand the characteristics of critical thinking based on current research, and what it means for teaching students to think critically in the higher education. We do so from the viewpoint of scientific thinking. We then turn to teaching and learning. The second aim is to outline the role of curriculum and assessment in developing and implementing critical thinking in classrooms and academic programmes. The third aim is to suggest future teaching 
research and practice in higher education. The goal is to deepen our understanding of how to enhance students' critical and scientific thinking.

\section{What Is Critical Thinking and How Does It Relate to Scientific Thinking?}

Critical thinking has been considered a foundation for participating in democracies for centuries, since the time of Socrates. It has been singled out as vital in growing up to be a genuinely autonomous and participating citizen of the modern society and one of the most important competencies for citizens of the $21^{\text {st }}$ century. It has also been emphasised as the most important competence universities are expected to cultivate in students during higher education (Halpern, 2014; Arum \& Roksa, 2011). Research on critical thinking is currently being pursued in at least two areas using very different approaches. One area is philosophical analysis of critical thinking. It focuses on the definition and justification of critical thinking as a theoretical concept. The second area is empirical analysis. It focuses on how individuals understand the nature of knowledge, how they construct and use knowledge, and what kinds of skills and strategies they utilise in the critical thinking process. In other words, empirical research focuses on the descriptive elements, and attempts to investigate how things are in the real world. For example, in the field of higher education, empirical research on critical thinking has focused on the development of critical thinking skills (e.g. Kuhn, 2005; Arum \& Roksa, 2011), while philosophical analyses have concentrated on the normative elements of the prevailing theorisation of critical thinking (e.g. Holma \& Hyytinen, 2015). The descriptive questions express an understanding of what something is, but they do not include an evaluation of how things should be. In contrast, the normative questions, such as what is the most adequate conception of knowledge, have been the central goals of the 
philosophical approach. Although philosophical and empirical analyses of critical thinking differ from each other, in educational research on critical thinking, the normative and descriptive elements of research are intertwined (Holma \& Hyytinen, 2015). The descriptive assumptions of critical thinking become normative in nature when these assumptions are regarded as goals of education and are thus promoted and assessed in the various phases of the educational path (cf. Hopmann, 2007).

There are various definitions of critical thinking in educational research. Common to these definitions is their view of critical thinking as a purposeful self-regulatory judgement about what to believe and to do (e.g. Facione, 1990; Ennis, 1991; Halpern, 2014). However, critical thinking cannot be regarded as just any thinking aimed at deciding what to believe and do (Bailin, Case, Coombs, \& Daniels, 1999). Such thinking can be naïve, rash or even careless. For example, one can come to believe on the basis of irrelevant reasons. Dewey's (1910, p. 9) analysis, the precursor to the modern critical thinking tradition, defined critical thinking as "active, persistent, and careful consideration of any belief or supposed form of knowledge in the light of the grounds that support it, and the further conclusions to which it tends". This suggests that thinking must meet some appropriate standards if it is to be regarded as critical thinking, for example, attempting to assess the evidence relevant to the belief or to the task (Bailin et al., 1999). Critical thinking, then, is conceptually connected to the epistemological ideal of rationality. Rationality requires the possibility of having some criteria or standards for evaluating beliefs and knowledge (Holma \& Hyytinen, 2015).

Dewey (1941) called these standards warranted assertions. In Dewey's (1941, p. 172) words, all knowledge "The position which I take, namely, that all knowledge, or 
warranted assertion, depends upon inquiry and that inquiry is, truistically, connected with what is questionable (and questioned) involves a sceptical element, or what Peirce called 'fallibilism'." In a similar vein, it has recently been noted that critical thinking is conceptually connected to the epistemological concept, fallibilism (Holma \& Hyytinen, 2015; Hyytinen, Nissinen, Ursin, Toom, \& Lindblom-Ylänne, 2015). According to Holma \& Hyytinen (2015, p. 10), fallibilism implies that "all human knowledge is uncertain, coheres with the evolutionary understanding of knowledge: the bodies of knowledge we now have may be mistaken and are thus possibly subject to revision, but they have, nevertheless, survived the process of evolution to this point; as such, they provide the best available starting point for how to proceed at the present moment with respect to further inquiry".

Another common way to conceptualise critical thinking is to enumerate thinking skills (Bailin et al., 1999; Fisher, 2011). For example, Fisher (2011, p. 8) listed the following skills:

"identify the elements in a reasoned case, especially reasons and conclusions; identify and evaluate assumptions; clarify and interpret expressions and ideas; judge the acceptability, especially the credibility, of claims; evaluate arguments of different kinds; analyse, evaluate and produce explanations; analyse, evaluate and make decisions; draw inferences; produce arguments" (see also Halpern, 2014; Ennis, 1993). 
However, critical thinking cannot be explained solely with the notion of a set of skills (e.g. Holma, 2015; Bailin et al., 1999); one who acquires a set of critical thinking skills does not use them all in a particular situation for one reason or another. It follows that it is not enough for one to possess the skills to assess the relevance of beliefs or knowledge, but one also needs to have the willingness to do so (Halpern, 2014; Hyytinen, 2015). American Philosophical Association's 'Delphi report' (Facione, 1990) and the consensus statement regarding the ideal critical thinker conclude that critical thinking is a combination of various dimensions of cognitive skills and affective dispositions. The cognitive skills include a purposeful, self-regulatory judgement which results in interpretation, analysis, evaluation, inference, and found explanation. The affective dispositions include open-minded, fair-minded and flexible in evaluation, willingness to reconsider, honesty in facing personal biases, diligence in seeking relevant information, reasonableness in the selection of criteria. Critical thinking is thus constituted by a variety of cognitive skills and dispositions to meet complex demands that make it possible to assess, evaluate, synthesise and interpret relevant information that is associated with a situation, and apply that information to solve a problem, to decide on a course of action, to find an answer to a given question or to reach a well-reasoned conclusion (Shavelson, Zlatkin-Troitschanskaia, \& Mariño, 2018). It involves open-minded and self-regulated thinking about alternative solutions and perspectives as well as possible consequences. Educating critical thinkers means working toward this ideal. For the purposes of this chapter, the distinction between cognitive skills (i.e. procedural knowledge) and affective dispositions is theoretically important. 
Researchers differ on the question of whether critical thinking is a general or generic skill that can be taught and applied across science disciplines or whether it is domain specific (Shavelson, 2018; Bailin \& Siegel, 2003; Barrie, 2006; Banta \& Pike, 2012; Oljar \& Koukal, 2019). In addition, there is research evidence that academics' views on teaching generic skills, such as critical thinking, vary (Barrie 2006, 2007). According to Barrie's $(2006,2007)$ phenomenographic analysis, some academics do not agree that teaching of generic skills is their responsibility. They assume that students have these skills already when they enter university. In addition, while for some academics this seems to be an issue of personal skills that are not related to domainspecific knowledge, others claim that critical thinking skills let students make use of or apply domain-specific knowledge (Barrie, 2006, 2007). Some academics have even claimed that critical thinking depends on domain expertise and thus cannot be assessed outside of the content of the discipline (see debate in Fischer, Chinn, Engelmann, \& Osborne, 2018).

We are thus led to a complex question. If we deny the possibility of developing more general critical thinking that can be transferred from one science domain to another, how can we promote it is as a vital competence for participating as a citizen in democratic society (Shavelson, 2018)? The interpretation of critical thinking as domainspecific in nature leads to the idea that critical thinking is all only for experts. This notion is inconsistent with the basic idea of the modern critical thinking tradition which promotes critical thinking as a foundation for participating in democracies and thus applicable for all citizens. However, it seems to us that this kind of dichotomy is unnecessary. Learning to think critically is a complex process in which both domain- 
specific knowledge and generic thinking skills are needed (Hyytinen, Toom, \& Postareff, 2018). Critical thinking demands a use of both declarative and procedural knowledge; i.e., students need some knowledge about the phenomenon before they can think about it critically. However, students need, at the same time, to possess necessary procedural and strategic knowledge to apply that declarative knowledge in context (Halpern, 2014; Hyytinen \& Toom, 2018; Segalàs, Mulder, \& Ferrer-Balas, 2012). In a similar vein, Bailin and Siegel (2003) have pointed out that although critical thinking is always connected to a particular context and it involves, to some extent, domain-specific knowledge, it does not follow that nothing general can be said about this issue. To a certain extent, the core elements of critical thinking are generalisable and applicable across different domains (cf. Siegel, 1991; Oljar \& Koukal, 2019). However, it seems reasonable to suggest there are domain-specific differences as to what critical thinking skills and dispositions are promoted during university studies.

There are several ways to interpret scientific thinking and critical thinking and their relationship. In general, scientific thinking and critical thinking overlap considerably with the demand for evidence for knowledge claims and action. However, on the one hand, in the Finnish higher education context, the term scientific thinking is a more commonly used term than critical thinking and sometimes these terms are used interchangeably. In this view, critical thinking is understood as a sub-component of the general competence of scientific thinking. However, on the other hand, critical thinking can be understood as a foundation for scientific thinking, following that scientific thinking is perceived as a narrower concept. In this view, scientific thinking is used to describe evidence-based thinking in science, social science, humanities, education, and 
business. This kind of view is emphasised in Europe, but not in the USA. In this chapter, we understand critical thinking in a broader sense. We view critical thinking as extending to the natural and social sciences and the humanities with an understanding of the unique application in each theoretically and methodologically (cf. Trigg, 2001; Niiniluoto, 1980; 1984).

\section{Why Do University Students Need to Be Able to Think Critically?}

Scientific research is intended to produce new information and new understandings and to explain the world around us. However, this does not mean that research can provide certain or final answers (cf. Niiniluoto, 1999). Research is an ongoing process of correcting and refining current conceptions and theories. The same kind of open-minded attitude is required from university students. University teachers in Western countries hope that students are engaged actively not listening passively, accepting everything they see and hear. Rather students are encouraged to think actively, to ask questions and to consider the reasons behind the arguments presented. Academic education cannot thus consist of information on a subject major only, but must also include the thinking skills for using that information. Students need to think critically to construct and situationally apply knowledge and understanding.

Critical thinking is needed to theoretically and conceptually elaborate the phenomenon being investigated, to gather and assess relevant scientific data and information, to use abstract scientific ideas to interpret them effectively, to come to wellreasoned scientific conclusions and solutions, testing them against relevant criteria and standards, as well as to communicate effectively with others in proposing solutions to complex scientific problems and understanding relationships between theory and practice 
(Paul \& Elder, 2008; Niiniluoto, 1980, 1984, 1999). Critical thinking also goes with inquiry and encourages thinking rather than accepting what told. "The heart of education lies exactly where traditional advocates of a liberal education always said it was -- in the processes of inquiry, learning and thinking rather than in the accumulation of disjointed skills and senescent information", as APA's Delphi report (1990, p. 2) sums up.

It is not surprising that critical thinking is promoted as an educational ideal (Arum \& Roksa, 2011; Halpern, 2014). Critical thinking is essential as a tool of inquiry and learning and vice versa. Thus, it forms the foundation for scientific thinking. As such, critical thinking is also a liberating force in education and a powerful resource in one's professional and personal life (APA's Delphi report, 1990). While not synonymous with personal traits, critical thinking can be grasped in terms of intellectual resources (see Bailin et al., 1999). Critical thinking is not something inborn either; we can learn to think critically and teach it (Halpern, 2014). Critical thinking skills are also so-called transferable skills needed beyond academia, i.e., in the working world and civic life (e.g., Hyytinen et al., 2018; Shavelson, 2010a).

Critical thinking has been found to be an essential factor for university students in progressing successfully through their studies (Arum \& Roksa, 2011; Badcock, Pattison, \& Harris, 2010; Utriainen, Marttunen, Kallio, \& Tynjälä, 2016). Problems with critical thinking and reasoning may not only affect the quality of learning, but the inability to think critically can cause significant delays in studies (Arum \& Roksa, 2011). Although the importance of teaching critical thinking is widely promoted, there is evidence that higher education students differ in their ability to think critically (e.g., Arum \& Roksa, 2011; Evens, Verburgh, \& Elen, 2013; Hyytinen et al., 2015; Hyytinen, Löfström, \& 
Lindblom-Ylänne, 2017; Hyytinen et al., 2018). While many students progress in these skills during their university studies, Arum and Roksa (2011) found that many students do not learn to think critically during university education.

In summary, university students need, at least, to be able to think critically to engage reasonably in democratic society, to do science, and to pose questions and problems as well as evaluate knowledge independently rather than repeating what has been told. Critical thinking captures the essential thinking and reasoning skills and thus forms a basis for scientific thinking. Critical thinking has also been found to be essential for learning and progressing in higher education and it can be learned as intellectual resource.

\section{Teaching Critical Thinking in a Way That Also Develops Scientific Thinking and}

\section{Academic Competence}

Educational researchers agree on the features of learning activities that would promote learning to think critically. These features include: facing open-ended problems, encountering real-world complexity, utilising multiple knowledge sources, developing knowledge artefacts to explicate thinking, utilising collective efforts and group resources instead of favouring individual student work, integrating rich use of modern technologies into the work processes (e.g., Marton \& Trigwell, 2000; Bereiter, 2002; Brooks \& Everett, 2009; Mills-Dick \& Hull, 2011; Phielix, Prins, Kirschner, Erkens, \& Jaspers, 2011), and teamwork, project work, and multidisciplinary collaboration (Denton \& McDonagh, 2005). Moreover, a number of pedagogical models have been suggested for promoting critical thinking. This includes problem-based learning (Hmelo-Silver, 2004; Dunlap, 2005), project-based learning (Bell, 2010; Helle et al., 2006), inquiry-based 
learning (Hofstein, Shore, \& Kipnis, 2004), learning by design (Vartiainen, Liljeström, \& Enkenberg, 2012; Healy, 2008), cooperative learning (Gillies, 2004), short novels and discussion borne out of the problems/questions encountered in narrative fiction (Tomperi, 2017), and concept maps (see Ruiz-Primo, Schultz, \& Shavelson, 2001). In this way students encounter the complexity of the phenomena being explored, search and evaluate a variety of knowledge sources, define the core problems to be solved, and based on thorough elaboration, formulate justifications for the solutions based on the knowledge sources.

Focusing on a single teaching method, such as problem-based learning, however, is not adequate. Rather, how we use the various pedagogical methods is more crucial than the methods themselves. If higher education is to contribute to the development of critical thinking, the whole teaching-learning environment needs to be purposefully designed to that end (Arum \& Roksa, 2011; Halpern, 2014). Moreover, teaching critical thinking needs to be built by combining both bottom up (i.e. student-driven) and top down (i.e. teacher-driven) approaches to teaching (Neisser, 1967) as well as by modelling reasoning or using realistic and authentic dilemmas and tasks (Shavelson, 2018). Teaching and learning need to be intertwined in solving real scientific mono- or multidisciplinary problems and questions. According to Bailin et al. (1999), teaching critical thinking should contain at least the following three components in a variety of learning situations in order to support the growth of students' intellectual thinking and to reach the core of critical thinking:

1. Engaging students in dealing with tasks that require reasoned judgement or assessment. 
2. Helping students develop intellectual resources for dealing with these tasks.

3. Providing an environment in which critical thinking is valued and students are encouraged and supported in their attempts to think critically and engage in critical discussion.

Learning occurs when teaching critical thinking is explicitly embedded in several courses throughout the curriculum and provides feedback that informs students as how to improve and build their critical thinking skills (e.g. Abrami et al., 2008; Arum \& Roksa, 2011; Halpern, 2014; Shavelson, 2018; Krolak-Schwerdt, Pitten Cate, \& Hörstermann, 2018). The development of critical thinking also requires teaching and learning activities that support metacognitive monitoring of thinking processes (Halpern, 2014; Virtanen \& Tynjälä, 2018). Arum and Roksa's (2011) longitudinal study showed that putting significant effort into studying, having teachers who hold high expectations and share collective responsibility for learning, and offer courses that require rigorous academic work, are associated with improved performance on tasks requiring critical thinking, complex reasoning and written communication. Teaching that involves student collaboration and interaction has been shown to support the acquisition of critical thinking, problem solving, and decision making (Virtanen \& Tynjälä, 2018). In contrast, lecturing and working alone were negatively related to learning such skills. Furthermore, teaching critical thinking can fail if it is not connected to disciplinary knowledge and practices (Samarapungavan, 2018).

Teaching students to think critically, then, requires holistic approaches that unify subject-matter learning, critical thinking and metacognitive skills. One challenge associated with this holistic view is for teachers to realise that the question is one of how 
to teach and not just what to teach. Yet higher education teachers are not necessarily well prepared to teach and assess critical thinking in a way that best supports growth of students' understanding and reasoning skills. The evidence shows that there is a huge variation between teachers (Barrie, 2006; 2007; Ayala et al., 2018; Shavelson, 2018). Most teachers, then, will have to learn to teach differently.

A related challenge is that teachers resist change. From the holistic perspective, teachers need incentives to take risks in changing. Otherwise, why would they change what they know "works": teaching declarative knowledge top down?

\section{Anchoring Critical Thinking to the Curriculum}

The discussion concerning teaching critical thinking could easily remain abstract or focus on certain specific teaching methods, assignments, taxonomies or tools. This is not our intent. More attention should be paid to the coherence of the curriculum and systematic integration of learning critical thinking throughout students' studies. Virtanen and Tynjälä's (2018) research showed that learning to think critically is a long process involving various teaching methods. An ability to think critically needs to be practised in multiple different contexts, on various tasks, combining theory and practice, alone, and together with others, and over time (cf. Arum \& Roksa, 2011; Virtanen \& Tynjälä, 2018). Students learning to think critically depends on how critical thinking is taught; students learn what they do (Biggs \& Tang, 2009). Consequently, teaching critical thinking needs to be aligned at a programme level. This means that learning to think critically should be expressed in learning outcomes, and its learning needs to be taken into account systematically in teaching methods, students' assignments and in assessment aligned with learning outcomes (cf. Abrami et al., 2008). It is important that such learning is integrated 
in domain specific courses; otherwise, it might remain separate and superficial in its core aspects.

Addressing critical thinking solely in a specialised course or relying solely on one specific teaching method is inadequate (Virtanen \& Tynjälä, 2018). Moreover, the risk is that teaching critical thinking will remain an incidental or isolated topic, if not integrated in learning goals, various teaching practices, and assessment in courses across the curriculum. The same risk appears if teaching decisions are left up to individual teachers of varying views of what is important to teach in their classes and how to do so.

Successful integration at the curriculum level involves collaboration between teachers. Teachers need to be ready to synchronise their courses among each other in a way that supports the attainment of learning outcomes (Arum \& Roksa, 2011; Jenert, 2014).

Critical thinking is an important part of scientific thinking, since it captures the core thinking and reasoning skills as described earlier. It also paves the way for students to progress in their higher education studies and enhance their academic competence. At the individual teacher level, critical thinking needs to be integrated into teaching goals, student in and out of class activities, and outcomes. At a department or institutional level, critical thinking needs to be integrated into the curriculum across teachers, courses within and across departments (cf. Arum \& Roksa, 2011; Toom, 2017).

\section{Conclusion}

The aim of teaching students to think critically is consistent with the epistemological ideal of rationality (Holma \& Hyytinen, 2015; Oljar \& Koukal, 2019). Critical thinking can be understood as a life skill that is applicable across disciplines (Oljar \& Koukal, 2019). A critical thinker needs to have knowledge of what is 
reasonable, the thinking skills to evaluate and use that knowledge, as well as dispositions to do so (Facione, 1990; Halpern, 2014; Hyytinen et al., 2015). Critical thinking also makes possible the assessment, evaluation, synthesis and interpretation of relevant scientific theories and empirical knowledge. It is context and action oriented in solving problems, deciding on a course of action, reaching well-reasoned conclusions and solutions, testing them against relevant criteria and standards, and communicating them effectively to others (Paul \& Elder, 2008; Shavelson, 2010b; Niiniluoto 1980, 1984; Rapanta, Garcia-Mila, \& Gilabert, 2013). This is all necessary if we want to educate skilful, competent students in an academic domain as well as educate them to become autonomous citizens of the $21^{\text {st }}$ Century and develop their scientific thinking skills.

Students begin to learn to think critically when their teaching is explicitly integrated into one domain-specific course. But to be effective it needs to be integrated into courses throughout the curriculum. Critical thinking is learned when domainspecific, procedural and self-regulative knowledge are connected with each other, as well as when teaching and learning activities set tasks for students to construct knowledge and skills in complex situations. Students need to put significant effort into learning to think critically, by studying and working alone and together (e.g. Arum \& Roksa, 2011; Muukkonen et al., 2017; Samarapungavan, 2018; Toom, 2017; Virtanen \& Tynjälä, 2018).

Critical thinking, then, should be recognised as an important outcome of higher education; curricula and course outlines should be aligned to produce this outcome. This is the only way to prevent critical-thinking teaching from becoming incidental in a random selection of courses. In order to provide sufficient coverage and alignment, study 
programmes need to be viewed as a whole. Teachers need to recognise that they have an individual and a collective responsibility for teaching students to think critically. Teachers need also need to have a clear understanding of what critical thinking is and why it important to teach. They should have the pedagogical competence to integrate thinking to various disciplinary topics and utilise a variety of teaching and assessment methods to enhance it. Finally, teachers need administrative and peer support in developing pedagogical competencies that enable them to ingrate the elements of critical thinking and reasoning in their teaching practices (Arum \& Roksa, 2011; Jenert, 2014).

We have a lot to learn about teaching and learning to think critically. For example, a complex issue still to be understood is how students' critical thinking develops during higher education when it is anchored to the curriculum. Is the development process faster than what is currently the case? What kind of associations can be found between student learning to think critically, teachers' teaching and characteristics of learning environment? How do students learn the skills related to critical and scientific thinking, how do they progress in these skills and how does the mastery of certain skills enhance mastery of others? In addition, we might ask, what are the threshold skills and dispositions that should be learned during higher education? That is, which qualities are necessary for becoming and being a critical thinker in school, at work, and throughout life? Furthermore, how do domain-general or domain-specific competencies impact critical thinking, and what kind of variation-if any-can be found between the domains? How do all these factors influence higher education students' thinking and reasoning skills? Finally, we need to understand similarities and variations 
in the pedagogical competences to teach critical and scientific thinking among academics in different disciplines and support teachers in developing these competencies. 


\section{References}

Abrami, P. C., Bernard, R. M., Borokhovski, E., Wade, A., Surkes, M. A., Tamim, R., \& Zhang, D. (2008). Instructional interventions affecting critical thinking skills and dispositions: A stage 1 meta-analysis. Review of Educational Research, 78(4), 1102-1134. https://doi.org/10.3102/0034654308326084

American Educational Research Association (AERA), American Psychological Association (APA), \& National Council on Measurement in Education (NCME). (2014). Standards for educational and psychological testing. Washington, DC: American Educational Research Association.

Facione, P. A. (1990). Critical thinking: A statement of expert consensus for purposes of educational assessment and instruction. Research findings and recommendations. Newark, DE: American Philosophical Association. (ERIC Document Reproduction Service No. ED315423)

Arum, R., \& Roksa, J. (2011). Academically adrift. Limited learning on college campuses. Chicago, IL: The University of Chicago Press.

Ayala, C. C., Shavelson, R. J., Araceli Ruiz-Primo, M., Brandon, P. R., Yin, Y., Furtak, E. M., Young, D. B., \& Tomita, M. K. (2008). From formal embedded assessments to reflective lessons: The development of formative assessment studies. Applied Measurement in Education, 21(4), 315-334. https://doi.org/10.1080/08957340802347787

Badcock, P. B. T., Pattison, P. E., \& Harris, K-L. (2010). Developing generic skills through university study: a study of arts, science and engineering in Australia. Higher Education, 60(4), 441-458. https://doi.org/10.1007/s10734-010-9308-8 
Bailin, S., Case, R., Coombs, J. R., \& Daniels, L. B. (1999). Conceptualizing critical thinking. Journal of Curriculum Studies, 31(3), 285-302, https://doi.org/10.1080/002202799183133

Bailin, S., \& Siegel, H. (2003). Critical thinking. In N. Blake, P. Smeyers, R. Smith, \& P. Standish (eds.), The Blackwell guide to the philosophy of education (pp. 181193). Oxford: Blackwell Publishing.

Banta, T., \& Pike, G. (2012). Making the case against - One more time. Occasional paper \#15. National Institute for Learning Outcomes Assessment. Retrieved from http://learningoutcomesassessment.org/documents/HerringPaperFINAL.pdf

Barrie, S. C. (2006). Understanding what we mean by the generic attributes of graduates. Higher Education, 51(2), 215-241. https://doi.org/10.1007/s10734-004-6384-7

Barrie, S. C. (2007). A conceptual framework for the teaching and learning of generic graduate attributes. Studies in Higher Education, 3(4), 439-458, https://doi.org/10.1080/03075070701476100

Bell, S. (2010). Project-based learning for the 21st Century: Skills for the future. The Clearing House: A Journal of Educational Strategies, Issues and Ideas, 83(2), 3943. https://doi.org/10.1080/00098650903505415

Bereiter, C. (2002). Education and mind in the knowledge age. Hillsdale: Erlbaum.

Bok, D. (2006). Our underachieving colleges. A candid look at how much students learn and why they should be learning more. Princeton, NJ: Princeton University Press.

Brooks, R., \& Everett, G. (2009). Post-graduation reflections on the value of a degree. British Educational Research Journal, 35(3), 333-349. https://doi.org/10.1080/01411920802044370 
Denton, H., \& McDonagh, D. (2005). An exercise in symbiosis: Undergraduate designers and a company product development team working together. The Design Journal, 8(1), 41-51. https://doi.org/10.2752/146069205789338315

Dewey, J. (1910). How we think. Boston, MA: D. C. Heath \& Co.

Dewey, J. (1941). Propositions, warranted assertibility, and truth. The Journal of Philosophy, 38(7), 169-186. https://doi.org/10.2307/2017978

Dowd, J. E., Thompson, R. J., Schiff, L. A., \& Reynolds, J. A. (2018). Understanding the complex relationship between critical thinking and science reasoning among undergraduate thesis writers. CBE life sciences education, 17(1), 1-10. https://doi.org/10.1187/cbe.17-03-0052.

Dunlap, J. (2005). Problem-based learning and self-efficacy: How a capstone course prepares students for a profession. Educational Technology Research and Development, 53(1), 65-83. https://doi.org/10.1007/BF02504858

Ennis, R. (1991). Critical thinking: a streamlined conception. Teaching Philosophy, 14(1), 5-24. https://doi.org/10.5840/teachphil19911412

Ennis, R. (1993). Critical thinking assessment. Theory Into Practice, 32(3), 179-186, https://doi.org/10.1080/00405849309543594

Evens, M., Verburgh, A., \& Elen, J. (2013). Critical thinking in college freshmen: The impact of secondary and higher education. International Journal of Higher Education, 2(3), 139-151. https://doi.org/10.5430/ijhe.v2n3p139

Fisher, A. (2011). Critical thinking: An introduction. Cambridge: Cambridge University press. 
Fischer, F., Chinn, C. A., Engelmann, K., \& Osborne, J. (2018) (eds.) Scientific reasoning and argumentation: The roles of domain-specific and domain-general knowledge. New York, NY: Routledge.

Gillies, R. (2004). The effects of cooperative learning on junior high school students during small group learning. Learning and Instruction, 14(2), 197-213. https://doi.org/10.1016/S0959-4752(03)00068-9

Greiff, S., Wüstenberg, S., Csapó, B., Demetriou, A., Hautamäki, J., Graesser, A. \& Martin, R. (2014). Domain-general problem solving skills and education in the 21st century. Educational Research Review, 13, 74-83. https://doi.org/10.1016/j.edurev.2014.10.002

Halpern, D. F. (2014). Thought and knowledge (5th ed.). New York, NY: Psychology Press.

Healy, A. (Ed.) (2008). Multiliteracies and diversity in education. Melbourne, Australia: Oxford University Press.

Helle, L., Tynjälä, P., \& Olkinuora, E. (2006). Project-based learning in post-secondary education - theory, practice and rubber sling shots. Higher Education, 51(2), 287-314. https://doi.org/10.1007/s10734-004-6386-5

Hmelo-Silver, C. (2004). Problem-based learning: What and how do students learn? Educational Psychology Review, 16(3), 235-266. https://doi.org/10.1023/B:EDPR.0000034022.16470.f3

Hofstein, A., Shore, R., \& Kipnis, M. (2004). Providing high school chemistry students with opportunities to develop learning skills in an inquiry-type laboratory-a case 
study. International Journal of Science Education, 26(1), 47-62.

https://doi.org/10.1080/0950069032000070342

Holma, K. (2015). The critical spirit: Emotional and moral dimensions of critical thinking. Studier I Pcedagogisk Filosofi, 4(1), 17-28. https://doi.org/10.7146/spf.v4i1.18280

Holma, K., \& Hyytinen, H. (equal contribution) (2015). The philosophy of personal epistemology. Theory and Research in Education, 13(3), 334-350. https://doi.org/10.1177/1477878515606608

Hopmann, S. (2007). Restrained teaching: the common core of Didaktik. European Educational Research Journal, 6(2), 109-124. https://doi.org/10.2304/eerj.2007.6.2.109

Hyytinen, H., Nissinen, K., Ursin, J., Toom, A., \& Lindblom-Ylänne, S. (2015). Problematising the equivalence of the test results of performance-based critical thinking tests for undergraduate students. Studies in Educational Evaluation, 44, 1-8. https://doi.org/10.1016/j.stueduc.2014.11.001

Hyytinen, H., Löfström, E., \& Lindblom-Ylänne, S. (2017). Challenges in argumentation and paraphrasing among beginning students in educational science. Scandinavian Journal of Educational Research, 61(4), 411-429. https://doi.org/10.1080/00313831.2016.1147072

Hyytinen, H., \& Toom, A. (2018). Developing a performance assessment task in the Finnish higher education context: conceptual and empirical insights. Submitted for publication. 
Hyytinen, H., Toom, A., \& Postareff, L. (2018). Unraveling the complex relationship in critical thinking, approaches to learning and self-efficacy beliefs among first-year educational science students. Learning and Individual Differences, 67, 132-142. https://doi.org/10.1016/j.lindif.2018.08.004

Jenert, T. (2014). Implementing-oriented study programmes at university: The challenge of academic culture. Zeitschrift für Hochschulentwicklung, 9(2), 1-12. Retrieved from https://www.alexandria.unisg.ch/publications/230455

Kadriye, E. \& Oliveri, M. E. (2016.) In search of validity evidence in support of the interpretation and use of assessments of complex constructs: Discussion of research on assessing 21st Century skills, Applied Measurement in Education, 29(4), 310-318. https://doi.org/10.1080/08957347.2016.1209210

Korhonen, V., Inkinen, M., Mattsson, M., \& Toom, A. (2017). Student engagement and the transition from the first to second year in higher education. In E. Kyndt, V. Donche, K. Trigwell, \& S. Lindblom-Ylänne (Eds.), Higher education transitions: Theory and research (pp. 113-134). London: Routledge.

Krolak-Schwerdt, S., Pitten Cate, I. M., \& Hörstermann, T. (2018). Teachers' judgments and decision-making: studies concerning the transition from primary to secondary education and their implications for teacher education. In O. ZlatkinTroitschanskaia, M. Toepper, H. A. Pant, C. Lautenbach, \& C. Kuhn (Eds.). Assessment of learning outcomes in higher education - Cross-national comparisons and perspectives (pp. 73-101). Wiesbaden: Springer. https://doi.org/10.1007/978-3-319-74338-7_5

Kuhn, D. (2005). Education for thinking. Cambridge, MA: Harvard University Press. 
Marton, F., \& Trigwell, K. (2000). Variatio est mater studiorum. Higher Education Research \& Development, 19(3), 381-395. https://doi.org/10.1080/07294360020021455

Mills-Dick, K., \& Hull, J. M. (2011). Collaborative research: Empowering students and connecting to community. Journal of Public Health Management \& Practice, 17(4), 381-387. https://doi.org/10.1097/PHH.0b013e3182140c2f

Muukkonen, H., Lakkala, M., Toom, A., \& Ilomäki, L. (2017). Assessment of competences in knowledge work and object-bound collaboration during higher education courses. In E. Kyndt, V, Donche, K. Trigwell, \& S. Lindblom-Ylänne (Eds.), Higher education transitions: Theory and research (pp. 288-305). London: Routledge.

Neisser, U. (1967). Cognitive Psychology. New York, NY: Appleton-Century-Crofts. Niiniluoto, I. (1980). Johdatus tieteenfilosofiaan. Helsinki: Otava.

Niiniluoto, I. (1984). Tieteellinen päättely ja selittäminen. Helsinki: Otava.

Niiniluoto, I. (1999). Critical Scientific Realism. Oxford: Oxford University Press.

Oljar, E., \& Koukal, D. R. (2019, February 3). How to make students better thinkers. The Chronicle of Higher Education. Retrieved from https://www.chronicle.com/article/How-to-Make-Students-Better/245576

Paul, R., \& Elder, L. (2008). The thinker's guide to scientific thinking: Based on critical thinking concepts and principles. Foundation for Critical Thinking.

Phielix, C., Prins, F. J., Kirschner, P. A., Erkens, G., \& Jaspers, J. (2011). Group awareness of social and cognitive performance in a CSCL environment: Effects of 
a peer feedback and reflection tool. Computers in Human Behavior, 27(3), 10871102. https://doi.org/10.1016/j.chb.2010.06.024

Rapanta, C., Garcia-Mila, M., \& Gilabert, S. (2013). What is meant by argumentative competence? An integrative review of methods of analysis and assessment in education. Review of Educational Research, 83(4), 483-520. https://doi.org/10.3102/0034654313487606

Ruiz-Primo, M., Schultz, S. E., Li, M., \& Shavelson, R. J. (2001). Comparison of the reliability and validity of scores from two concept-mapping techniques. Journal of Research in Science Teaching, 38(2), 260-278. https://doi.org/10.1002/10982736(200102)38:2<260::AID-TEA1005>3.0.CO;2-F

Samarapungavan, A. (2018). Construing scientific evidence: The role of disciplinary knowledge in reasoning with and about evidence in scientific practice. In F. Fischer, C. A. Chinn, K. Engelmann, J. Osborne (eds.), Scientific reasoning and argumentation: The roles of domain-specific and domain-general knowledge (pp. 56-76). New York, NY: Routledge.

Segalàs, J., Mulder, K. F., \& Ferrer-Balas, D. (2012). What do EESD “experts” think sustainability is? Which pedagogy is suitable to learn it? Results from interviews and Cmaps analysis gathered at EESD 2008. International Journal of Sustainability in Higher Education, 13(3), 293-304. https://doi.org/10.1108/14676371211242599

Shavelson, R. J. (2010a). On the measurement of competency. Empirical Research in Vocational Education and Training, 2(1), 41-63. Retrieved from http://ervet.ch/pdf/PDF_V2_Issue1/shavelson.pdf 
Shavelson, R. J. (2010b). Measuring college learning responsibly: Accountability in a new era. Stanford, CA: Stanford University Press.

Shavelson, R. (2018). Discussion of papers and reflections on "exploring the limits of domain-generality". In F. Fischer, C. A. Chinn, K. Engelmann, J. Osborne (eds.), Scientific reasoning and argumentation: The roles of domain-specific and domain-general knowledge (pp. 112-118). New York, NY: Routledge.

Shavelson, R. J., Zlatkin-Troitschanskaia, O., \& Mariño, J. (2018). International performance assessment of learning in higher education (iPAL): Research and development. In O. Zlatkin-Troitschanskaia, M. Toepper, H. A. Pant, C. Lautenbach, \& C. Kuhn (Eds.). Assessment of learning outcomes in higher education - Cross-national comparisons and perspectives (pp. 193-214). Wiesbaden: Springer. https://doi.org/10.1007/978-3-319-74338-7_10

Siegel, H. (1991). The generalizability of critical thinking. Educational Philosophy and Theory, 23(1), 18-30. https://doi.org/10.1111/j.1469-5812.1991.tb00173.x

Strijbos, J., Engels, N., \& Struyven, K. (2015). Criteria and standards of generic competences at bachelor degree level: a review study. Educational Research Review, 14, 18-32. https://doi.org/10.1016/j.edurev.2015.01.001

Tremblay, K., Lalancette, D., \& Roseveare, D. (2012). Assessment of higher education learning outcomes. In Feasibility study report. Design and implementation (Vol. 1). OECD. Retrieved from http://www.oecd.org/edu/skills-beyondschool/AHELOFSReportVolume1.pdf 
Tomperi, T. (2017). Kriittisen ajattelun opettaminen ja filosofia. Pedagogisia perusteita. Niin \& Näin, 4(17), 95-112. Retrieved from https://netn.fi/artikkeli/kriittisenajattelun-opettaminen-ja-filosofia-pedagogisia-perusteita

Toom, A. (2017). Teacher's professional competencies: A complex divide between teacher's work, teacher knowledge and teacher education. In D. J. Clandinin \& J. Husu (Eds.), The SAGE handbook of research on teacher education (pp. 803819). London: SAGE Publishers.

Tynjälä, P., \& Gijbels, D. (2012). Changing world: Changing pedagogy. In P. Tynjälä, M-L. Stenström, \& M. Saarnivaara (eds.), Transitions and transformations in learning and education. Netherlands: Springer. https://doi.org/10.1007/978-94007-2312-2_13

Trigg, R. (2001). Understanding social science: A philosophical introduction to the social sciences. Oxford: Blackwell publishing.

Utriainen, J., Marttunen, M., Kallio, E., \& Tynjälä, P. (2016). University applicants' critical thinking skills: The case of the Finnish educational sciences. Scandinavian Journal of Educational Research, 61, 629-649. https://doi.org/10.1080/00313831.2016.1173092

Vartiainen, H., Liljeström, A., \& Enkenberg, J. (2012). Design-oriented pedagogy for technology-enhanced learning to cross over the borders between formal and informal environments. Journal of Universal Computer Science, 18(15), 20972119. https://doi.org/10.3217/jucs-018-15-2097 
Virtanen, A., \& Tynjälä, P. (2018). Factors explaining the learning of generic skills: a study of university students' experiences. Teaching in Higher Education, https://doi.org/10.1080/13562517.2018.1515195

Zahner, D., \& Ciolfi, A. (2018). International comparison of a performance-based assessment in Higher education. In O. Zlatkin-Troitschanskaia, M. Toepper, H. A. Pant, C. Lautenbach, \& C. Kuhn (Eds.). Assessment of learning outcomes in higher education - Cross-national comparisons and perspectives (pp. 215-244). Wiesbaden: Springer. https://doi.org/10.1007/978-3-319-74338-7_11

Zlatkin-Troitschanskaia, O., Shavelson, R. J., \& Kuhn, C. (2015). The international state of research on measurement of competency in higher education. Studies in Higher Education, 40(3), 393-411. https://doi.org/10.1080/03075079.2015.1004241 